\title{
Profissão Docente: Formação e Prática de Professores de História no Ensino Médio
}

\author{
Serlei Maria Fischer Ranzi ${ }^{1}$ \\ Cláudia Regina Kawka Martins ${ }^{2}$
}

\section{RESUMO}

0 presente artigo tem por objetivo apresentar e discutir resultados da pesquisa "A disciplina escolar de História e a prática dos professores do Ensino Médio no Paraná: uma análise dos últimos trinta anos", a qual vem sendo realizada mediante questionários dirigidos e entrevistas com alguns professores de História que atuam ou atuaram na rede pública paranaense, com o intuito de levantar aspectos da sua formação, do fazer pedagógico do professor, do conhecimento, análise e aplicação do currículo e sua relação com a disciplina de História. Neste artigo apresentamos algumas questões referentes ao impacto da formação na prática desses professores, e às representações e prática docente no ensino médio.

Palavras-chave: ensino de História, formação e prática de professores.

Muito se tem estudado no Brasil e no exterior sobre livros didáticos, currículos oficiais, mas muito pouco se sabe sobre um elemento essencial na análise da cultura escolar: a atividade docente desenvolvida em sala de aula. CATANI confirma isso num exame da produção brasileira sobre estudos de História da Profissão Docente no Brasil. Para ela, embora numerosos os estudos históricos sobre formação de professores, instituições, saberes, atividades docentes e organização da categoria do magistério, a expressão "história da profissão docente" é mais rara. "As análises são mais abundantes entre nós quando o eixo central localiza-se na dimensão 'organização da categoria profissional e

\footnotetext{
1 Professora de Metodologia e Prática de Ensino de História e do Programa de Pós-Graduação em Educação da UFPR na linha História e Historiografia da Educação - serlei@ufpr.br

2 Professora de História do Colégio Militar de Curitiba, de Metodologia do Ensino de História do Centro Universitário Campos de Andrade e doutoranda do Programa de Pós-Graduação em Educação da UFPR, na linha História e Historiografia da Educação-mkawka@uol.com.br.
} 
relações com o Estado' e quando a periodização toma como marcos períodos mais recentes". (2000, p. 587). Outra preocupação manifestada pela autora em relação aos estudos sobre a história da profissão docente refere-se a uma possível dispersão temática, ou seja, os estudos existentes não levam em consideração as várias dimensões do exercício profissional do magistério, o que envolveria, na sua análise, de forma simultânea e integrada, aspectos da formação, saberes, instituição, prática, relações com o Estado e formas de organização.

Mais recentemente, há uma preocupação em recortar mais este tipo de estudo relacionando-o com as questões ligadas à constituição, organização e finalidade de uma determinada disciplina escolar e fazendo um inventário sistemático das práticas, período por período, para observar as modificações, as mais sutis, de geração em geração. (JULIA, 2001, p. 1-2). Assim não basta apenas estudar a questão da legislação educacional, mas a prática das organizações escolares, enfim, a cultura escolar como um todo. Entendemos aqui cultura escolar como "um conjunto de normas que definem conhecimentos a ensinar e condutas a inculcar, e um conjunto de práticas que permitem a transmissão desses conhecimentos e a incorporação desses comportamentos; normas e práticas coordenadas a finalidades que podem variar segundo as épocas." (JULIA, 2001, p. 9).

Com esta preocupação estamos desenvolvendo uma pesquisa para analisar os professores e sua prática numa relação direta com o percurso da disciplina de História no Brasil e no Paraná nos últimos 30 anos. ${ }^{3} 0$ trabalho de entrevistas está sendo feito em duas etapas: num primeiro momento, as questões foram dirigidas e abarcaram um número maior de professores (75 professores $)^{4}$, sem levar em consideração o seu tempo de atuação no magistério. Num segundo momento, estamos selecionando, entre aqueles que responderam às questões dirigidas, um número menor de professores com diferentes etapas no exercício do magistério, para uma entrevista aberta.

3 Essa pesquisa intitula-se "A disciplina escolar de História e a prática dos professores do Ensino Médio no Paraná: uma análise dos últimos trinta anos" e está vinculada ao projeto integrado "História da Educação: Instituições, Intelectuais e Cultura Escolar" da linha de História e Historiografia da Educação, a qual faz parte do Programa de Pós-Graduação em Educação - Mestrado e Doutorado, da UFPR.

4 Segundo dados da SEED, do ano 2000, o número de professores de História que atendiam Curitiba e a Região Metropolitana era de 521. Na primeira etapa da pesquisa, recebemos o retorno de 75 entrevistas dirigidas. 
Entrevistamos até o momento cinco professores que atuam ou atuaram no ensino médio em escolas públicas de Curitiba e Região Metropolitana. Encontramos, entre os narradores, a professora Marlene, nascida em 1947, que se aposentou, decidiu que "nunca mais iria por um pé na escola", e, no entanto, voltou e está no terceiro padrão, com 35 anos de magistério. Ela teve sua formação inicial e média em colégios confessionais, é descendente de alemães e atribui uma forte influência étnica na sua formação. Cursou Estudos Sociais, licenciatura plena, em uma universidade particular, no interior do Estado do Paraná. Fez cursos de atualização, pós-graduação em Metodologia do Ensino de História, iniciou o trabalho de docência nas séries iniciais, depois passou a dar aulas no Ensino Fundamental e, por fim, no Ensino Médio. Afirma que na escolha da profissão e do curso de História houve um incentivo por parte do pai - que gostava de ler - e de uma irmã que foi sua professora de História.

0 professor Edson está em vias de se aposentar por problemas de saúde, mas fez da escola sua opção de vida. Terminou a Escola Normal em 1968, em Colorado, Norte do Paraná, e logo começou a trabalhar como professor primário. Veio para Curitiba cursar História, na Universidade Federal do Paraná, por opção pessoal: "Eu tentei fazer engenharia antes, para agradar a meu pai. Eu fiz 0 vestibular de engenharia, passei no vestibular, saí da escola. Agora eu vou fazer o que eu quero: História". Trabalhou muitos anos com Ensino Fundamental e desde 1991 trabalha com Ensino Médio no Colégio Estadual do Paraná.

Entrevistamos também a professora Maria Irmínia, que se aposentou porque foi desenvolver um trabalho mais burocrático e não suportou ter largado a sala de aula. Ela fez a formação das séries iniciais em escola pública, o ginásio em colégio confessional católico e cursou também a Escola Normal. Fez o curso de História na Universidade Federal do Paraná, na década de sessenta, pois na época a Escola Normal não permitia que ela fizesse o vestibular para Direito, como era desejo de seu pai. Na Universidade participou de um Centro de Estudos de História, foi em vários congressos apresentar trabalhos e afirma que teve uma boa formação acadêmica. Trabalhou durante muitos anos no Colégio Estadual do Paraná e, em 1986, deixou a sala de aula para trabalhar na Secretaria de Educação, onde permaneceu até sua aposentadoria, no início da década de noventa. 
0 professor Ariosvaldo iniciou no magistério quase por acaso, se afastou para "tentar a vida" em outra atividade, arrependeu-se e voltou para o magistério 12 anos depois. Ele concluiu seus estudos do ensino fundamental em colégio católico, em Porto Alegre. № $2^{\circ}$ grau, fez Técnico em Contabilidade. Cursou Filosofia, na década de setenta, numa universidade confessional, no Rio Grande do Sul, e fez uma complementação em História. Nunca pensou em ser professor de História. Trabalhou como contador, deu aulas de Inglês e, mais tarde, passou a dar aulas de Filosofia no mesmo colégio onde havia cursado o ensino fundamental. Trabalhou no Ensino Médio em vários colégios de Porto Alegre, durante cinco anos. Largou o magistério e veio para Curitiba, onde trabalhou por doze anos num empreendimento comercial particular. Voltou novamente para o magistério em 1992, para dar aulas de História no Ensino Médio, em escola pública, onde permanece até hoje, em dois padrões.

E, por fim, temos a professora Maria de Fátima, que estudou sempre em escola pública, fez Estudos Sociais - licenciatura curta, na UFPR: "0 que me levou a escolher na época, realmente, era uma falta de saber o que escolher, mas de certo modo, eu tinha uma professora, chamada Arlete, que ela dava uma aula de História muito diferente. Ela dava aula de História com músicas do Chico Buarque e eu comecei a me apaixonar por História. Mias naquele ano na Federal [...] tinha muitas pessoas para História, e o curso de Estudos Sociais tinha muita vaga. [...] Então foi assim, pela falta de conhecimento que eu tinha e pela oportunidade de ter um curso com muita possibilidade de entrar. Eu escolhi Estudos Sociais porque eu gostava de História e porque o curso que eu queria mesmo - Publicidade e Propaganda - eu não ia ter nenhuma chance de cursar." Anos depois, já no final da década de noventa, Maria de Fátima fez uma adaptação em História, na Faculdade Espírita. Na sua trajetória profissional, lecionou na prefeitura de São José dos Pinhais, em escolas estaduais - como professora de História e Geografia - foi também diretora de escola por um período e permanece até hoje nessa profissão, buscando no fim da carreira muito mais a comodidade de uma escola próxima de sua casa, dando aula de Geografia, do que se manter como titular na disciplina que motivou a sua formação complementar.

0 nosso trabalho, até esse momento, pautou-se mais no conhecimento ligado a aspectos da formação, do fazer pedagógico do professor, no 
conhecimento, análise e aplicação do currículo e na sua relação com a disciplina de História. Levamos em consideração as ações, as decisões e as posturas daqueles que estão envolvidos na prática educacional. Procuramos dar voz ao professor e relacionar as vivências dos professores em exercício com a sua própria prática docente.

Partimos da premissa de que o professor é, na verdade, um receptor das normas e das mudanças metodológicas propostas. No entanto, estamos tomando como pressuposto que o que é recebido é sempre diferente do que foi originalmente encaminhado, porque os receptores, de maneira consciente ou inconsciente, interpretam e adaptam idéias, costumes, imagens e tudo o que thes é oferecido.

Iniciamos com a perspectiva de analisar muitos casos na intenção de entender o consenso e as permanências na diversidade, o que há de comum, de compartilhado, com a possibilidade de evidenciar algumas tendências. $\mathrm{Na}$ sequiência a intenção foi estudar casos únicos para buscar, na relação representação-ação, os mecanismos cognitivos e afetivos na elaboração das representações, trabalhando mais na lógica da construção individual. (SPINK, 1994, p. 117-143).

Para apreender as diferentes representações sobre as práticas, analisar as singularidades dos percursos dos professores de História ao longo da sua carreira profissional e compreender os imperativos interiores que se concretizam na realização de um percurso, apelamos para as discussões e os trabalhos contemporâneos sobre o uso da memória na história e na educação. Buscamos na construção de memórias contemporâneas identificar, além do mero discurso histórico, as formas múltiplas e possivelmente conflitantes de rememoração e utilização do passado. (CHARTIER, 1996, 216).

Recorremos também a CERTEAU (1976) reconhecendo a necessidade de captar o "não-dito", analisar o discurso histórico na instituição em função da qual ele é organizado em silêncio. A escola, no seu cotidiano, é um exemplo, pois não dá para sonhar com uma renovação curricular que seja apenas assegurada pelas modificações dos seus conceitos, sem que haja uma transformação de situações estabelecidas. Para isso é necessário compreender o discurso e analisar as práticas na sua historicidade. 


\section{0 impacto da formação nas representaçöes sobre a pråtica docente}

Estudos sobre a profissão docente, através de relatos de experiência e de outras pesquisas, atestam o quanto é problemática para os professores a questão da formação. São manifestações a respeito da parte inicial dessa formação, no seu engajamento quando entra no campo profissional e no decorrer no trabalho em escolas de Ensino Fundamental e Médio. A formação inicial é considerada pelos depoentes, muitas vezes, como deficiente:

Eu acho que algumas disciplinas do curso de Estudos Sociais, dentro da política, eram fracas [...] a maioria (dos professores) eram muito fracos, por causa da própria grade que o regime militar impôs. A grade não permitia desenvolver mais. (Professora Marlene, 2002).

Ou então, na visão de outro narrador:

0 curso foi demasiadamente centrado na formação do pesquisador; eu fui preparado para não ser professor, eu fui preparado para ser pesquisador de História, mas os professores foram muito claros quando colocaram isso pra gente: 0 objetivo do curso de História da UFPR não era pra formar professores. (Professor Edson, 2001).

Para a professora Maria Irmínia, que cursou História na mesma universidade, a sensação é a mesma: "a minha formação de didática, melhor que a da faculdade, foi a da escola normal, tinha uns professores extraordinários [...]" Para dois, dos cinco professores entrevistados, a formação para ser professor veio da Escola Normal. Ambos colocam a importância desse nível de escolaridade no sucesso profíssional como professor.

Para esses dois professores, formados nas décadas de 60 e 70 , qual é 0 significado de formação que está subjacente no discurso? 0 que significa ser professor? Em ambos aparece claramente a lembrança de uma boa formação didática que a escola normal propiciou, principalmente na concepção do ofício do professor. Esta estaria ligada a uma visão de ensino-aprendizagem que permitiria adquirir competências profissionais mínimas, essencialmente práticas e tendo um bom referencial de base que a Universidade não propiciou? 
Para alguns, o início foi de maior dificuldade, nem sempre assumida nas falas. Ao longo das entrevistas, no entanto, as mudanças observadas pelo professor na sua prática revelam, em parte, os problemas na formação inicial:

Mudou tudo ou quase tudo. Antes eu ficava na minha posição e 0 aluno ali. Hoje não. Eu chego sempre mais próximo do aluno. Eu sou hoje uma outra professora. 0 relacionamento professor-aluno mudou, a minha maneira de ensinar História, antes eu cobrava fatos, datas, hoje eu relaciono com o presente, as avaliações também mudaram. Eu digo hoje: vocês não estão aqui para serem reprovados, não. É a experiência... hoje eu trabalho com o assunto, jogo perguntas para os alunos, levo textos de jornais, revistas, a questão do euro. No início o aluno não sabe nada, no final do ano ele já está melhor. Hoje eu faço relações com o presente. Para que eles sejam cidadãos, que vejam que eles fazem parte dessa sociedade. (Professora Marlene, 2002).

Constata-se que essa dificuldade inicial vai ser maior ou menor, dependendo do momento em que os profissionais assumem a sala de aula e se o fazem com um certo grau de autonomia e responsabilidade pessoal nas tomadas de decisão. Outras opiniões colhidas nas entrevistas com os professores indicam que $28,8 \%$ deles enfrentaram como primeira dificuldade na carreira do magistério a mediação entre os conteúdos acadêmicos è os conteúdos a serem ensinados. Em segundo lugar, 27,9\% dos professores colocam como empecilho inicial a falta de informações sobre as normatizações oficiais. Para suprir essa dificuldade inicial, muitos buscaram uma formação complementar. Quem tinha feito Estudos Sociais ou Filosofia, complementou com História. Mesmo com a complementação, a formação para a profissão docente, para uma mobilização dos saberes ainda não se mostrou suficiente, como observa uma das professoras:

Olha, pra profissão de professor não. Do nosso dia-a-dia, da nossa prática, daquela coisa de levar adiante ali...a sala de aula, eu verifico que o professor não é preparado na Universidade. Ele aprende muita teoria, ele aprende coisas a respeito do conteúdo que ele tem que ensinar, muitas pinceladas, eu não diria nem que é um todo. Fica muito assim na base, assim do teórico e do acadêmico. 
Lá, parece tão longe, sabe, daquilo que você, que você vai trabalhar. Agora, a parte de ser o professor, do dia-a-dia, de como você lidar com as diferenças, com a sala de aula, com o adolescente, e o jovem, e a criança, eu acho que não. Eu acho que, naquele tempo pelo menos, faltou. (Professora Maria de Fátima, 2002).

Por mais que falte uma clareza do que efetivamente faltou na sua formação, o professor indica que ela deveria ter sido diferente ${ }^{5}$, pois a classifica de muito teórica, muito acadêmica ou essencialmente voltada para a pesquisa. Devido a isso, cada um irá trabalhar os conteúdos, estabelecidos pelo currículo oficial, da sua maneira. Assim a seleção dos conteúdos não termina nas decisões governamentais, e sim tem sua continuidade dentro do cotidiano da sala de aula, onde realmente o currículo toma existência. GOODSON afirma que é importante estudar as histórias de vida dos professores para poder analisar melhor o currículo e a escolaridade. Para ele a investigação educacional precisa ser reconceitualizada, dando-se a chance para a voz do professor ser ouvida. "Ouvir a voz do professor devia ensinar-nos que 0 autobiográfico, a vida, é de grande interesse quando os professores falam do seu trabalho. [...] o que considero surpreendente, se não francamente injusto, é que durante tanto tempo os investigadores tenham considerado as narrativas dos professores como dados irrelevantes." (1995, p. 71).

Esta é uma afirmação que contribui para reiterar a importância da opção metodológica de dar voz a alguns professores que lecionaram nesse período que estamos pesquisando. A memória desses professores não é só deles, ela insere-se no grupo social em que eles vivem, ela é, sobretudo, um fenômeno coletivo. Como afirma HALBWACHS, "a memória individual não está inteiramente isolada e fechada. Um homem, para evocar seu próprio passado, tem freqüentemente necessidade de fazer apelo às lembranças dos outros. Ele se reporta a pontos de referência que existem fora dele, e que são fixados pela sociedade." (1990, p. 54). Portanto, quando o professor fala dele, da sua prática, ele também fala da dinâmica de sua escola e da imagem construída sobre o que é ser professor.

5 Por mais incompleta que possa parecer a formação do professor, "o ato de ensinar não pode ser analisado unicamente em termos de transmissão de conteúdos e de métodos, uma vez que são as comunicações verbais em classe, as interações vivenciadas, a relação e a variedade das ações em cada situação que permitirão ou não [...] o aprendizado em cada intervenção" (ALTET, 2001, p. 26). 
Quanto ao trabalho prático com a disciplina, uma ampla maioria dos professores, nas entrevistas dirigidas, entende como relevante trabalhar com projetos ou partir da realidade do aluno. Porém esta opção foi corroborada por apenas um dos professores na entrevista aberta. De qualquer forma, é recorrente a afirmação de que a prática em sala de aula, varia de professor para professor:

Certos professores desenvolvem uma relação extremamente rotineira com o seu trabalho: ficam sempre com o mesmo ano e quase nunca põem em causa o que fazem; tentam, pois, retomar, ano após ano, as mesmas preparações, os mesmos exemplos, o mesmo material. [...] Muitos outros não esperaram [...] para ir mais longe, procurando recriar meios de ensino em situações para as quais os manuais não têm resposta, modificar os conteúdos e as formas do trabalho escolar ou da avaliação. (PERRENOUD, 1993, p. 59).

Trabalhar com projeto é uma atividade que muitas vezes é sugerida pela direção das escolas como uma forma de fugir do tradicional - aula expositiva - e muitas vezes acaba sendo colocada em prática por professores que têm a escola como único investimento profissional e aceitam o desafio:

[...] e, além disso, a própria sistemática do colégio nos leva a pensar projetos, aqui nós trabalhamos com projetos, e isso estimula muito a criatividade. Porque uma coisa que é essencial para o professor é a criatividade, ele sempre procurar motivações novas. Motivações novas não são só utilização de recursos, livros, motivações novas devem despertar a curiosidade do aluno. A gente pode correr 0 risco de proporcionar muito lazer para os jovens, em qualquer área, e esquecer a discussão. (Professor Edson, 2001).

Nesse sentido as entrevistas abertas nos mostraram as singularidades dos caminhos e sugerem que há diferentes compreensões que podem ser atribuídas às diferentes formações dos professores. Para um professor, formado em uma Universidade Federal, mas também com formação bem fundamentada nos graus anteriores de ensino, com experiência docente bem diversificada, uma referência familiar na profissão docente, fica mais fácil, como ele mesmo afirma, seguir um caminho diferenciado: 
Tios professores, tias professoras, primos professores e eu fui criado então neste ambiente de professores e sempre tive muito acesso a livros, então fui ensinado a ler desde muito pequeno. 0 primeiro, uma coisa assim que eu lembro que foi muito marcante, a minha avó lendo comédia de Dante em italiano e os netos todos sentados no chão ouvindo. Porque o italiano foi a segunda língua que a gente convivia em casa. Uma outra coisa de muita sorte: aos nove anos me deram o primeiro livro, foi Dom Quixote de La Mancha, aí eu comecei a me interessar muito por leitura. Quando terminei o $1^{\circ}$ grau eu já tinha uma formação bastante razoável. $02^{\circ}$ grau eu fui obrigado a fazer na escola normal porque era 0 único curso que tinha em Colorado. Então eu vou começar praticamente aí a minha carreira de professor em função do $2^{\circ}$ grau que eu fiz, porque eu tenho o maior prazer, inclusive, quando eu vejo o meu diploma de professor primário. Terminei em 1968 e em 1969 comecei a trabalhar, daí não parei mais e $02^{\circ}$ grau, daí como decorrência, depois que fiz vestibular, eu já era professor, e fui assumir o $2^{\circ}$ grau apenas em 1991 no Estado efetivamente, mas a minha maior prática é com Ensino Fundamental. Então foi uma experiência boa. (Professor Edson, 2001)

Essa questão da influência da família na escolha da profissão também aparece em outra fala:

E eu sempre gostei porque eu sou de uma família de professores. Se você perguntar na minha família quem não é professor, é mais fácil que dizer do que quem é professor. Tanto a família do meu pai, ele era professor, meu avô professor, tinha um tio que era professor do Colégio Estadual também professor de História, o professor Rui, as minhas irmãs, as quatro são professoras, [...] a minha mãe, então acho que estava no sangue, ficou no sangue. (Professora Maria Irmínia, 2002).

0 relato do professor Edson, somado ao da professora Maria Irmínia, ambos com uma história familiar ligada à profissão de professor, ambos formados pela Universidade Pública, com uma dedicação total e única no ensino de História (nunca deram aula de outra disciplina), com a criatividade, a contínua formação como propósito a atingir na vida profissional - permite incluí-los numa tipificação do 
professor 'autônomo' 'responsável', capaz de avaliação e iniciativa na adaptação criativa de seus atos e de suas posturas às realidades do ofício. É um praticante que ultrapassa o imediatismo da realização cotidiana e de suas tarefas, pois posiciona a relação ensinar-aprender na dinâmica de um projeto para os alunos e para si mesmo na sociedade. Seu projeto pedagógico e seu projeto profissional são projetos humanos: conferem sentido e finalidade ao ofício e a ele próprio dentro do ofício. (BAILLAUQUES, 2001, p. 44).

Além das questões socioculturais que antecedem a sua profissionalização, identificamos outras que contribuem para o professor definir o seu papel na prática docente, o seu desempenho na construção de saberes escolares ${ }^{6}$. Muitas variáveis entram em jogo. Podemos distinguir três grandes conjuntos que vão pesar de maneira diferente segundo a idade, a formação e a carreira do professor: de um lado, estão os elementos exógenos que poderiam ser definidos como exteriores a ele como: programas, contratos institucionais, saberes de referência e livros didáticos; em seguida vêm os elementos endógenos: sua personalidade, seus gostos, suas escolhas, seus projetos e as representações que ele tem de sua função, de seu papel, da forma como ensina, daquilo que aprendeu, da definição mais ou menos consciente que ele dá do seu objeto de ensino e de suas finalidades, e, enfim, daquilo que assinalou como realidade da sala de aula, ou seja, os alunos tais quais eles são ou tais quais ele os vê. (LE PELLEC; MARCOS ALVAREZ, 1991, p.50).

Todo esse processo resulta também da relação que o professor tem com seu passado escolar. No processo de formação inicial de professores na Universidade, temos notado como os professores-estagiários se apropriam de práticas adotadas por seus professores e as reproduzem, repetem os mesmos mecanismos, demonstram dificuldade de romper com determinados padrões. A relação do professor com o seu passado escolar gera uma interdependência na forma de escolher os conteúdos, na relação com o aluno e com a

6 Observamos que não há um consenso entre os especialistas sobre a origem do saber escolar, sobre a relação que há entre o saber escolar e a produção acadêmica da disciplina de História, trata-se nos dois casos de saberes históricos. [...] Essa passagem denominada de recomposição, transposição ou elaboração didática, resulta de um conjunto de transformações, com fins de ensino, sobre o saber acadêmico: não somente uma redução e uma simplificação, mas também uma descontextualização, isto quer dizer, por fim, uma ruptura dos laços entre problemática e saberes e uma reconstrução, uma coerência segundo uma lógica própria na constituição do objeto de ensino. (GUYON; MOUSSEAU; TATIAUX-GUILLON, 1993, p. .90) 
aprendizagem da disciplina. A propósito, BAILLAUQuÉS sugere que "para alguém, que deseja tornar-se professor, o passado e 0 presente encontram-se no projeto social e também pessoal do eu. A idéia/visão da pessoa em seu ofício refere-se a sua experiência com os diferentes mestres com os quais teve contato: ela se projeta em seu horizonte e produz-se dentro de um estilo próprio nas expectativas e nos procedimentos de formação." (2001, p. 51).

Reforçando este argumento, KENSKI, afirma que "os professores criam formas personalizadas de atuar em sala de aula, não apenas baseados no conhecimento do conteúdo da disciplina e da metodologia de ensino específica, mas também de acordo com as vivências que tiveram e que a situação de ensino em que se encontram ajudam a recuperar." (19-, p. 46).

As respostas sobre o encaminhamento do trabalho pedagógico em sala de aula podem refletir a prática do professor, mas podem também refletir uma preocupação do entrevistado em dar a resposta que ele imagina ser a esperada, em função do que se acredita como ideal para a escola e o seu funcionamento.

Quando perguntados sobre o planejamento das aulas, a maioria dos professores afirma que ele foi sendo diversificado ao longo do tempo, que há uma maior preocupação hoje nas orientações oficiais com o como ensinar e com o que ensinar, sendo esta a maior mudança sentida pelo conjunto dos professores. Em contrapartida, eles perceberam uma menor preocupação do sistema educativo com o cumprimento do programa. Notadamente, dentre as questões relacionadas à prática docente, estas foram as que permitiram identificar um grau de maior aproximação no resultado dos dois instrumentos utilizados para entrevistar os professores.

Para concretizar uma certa atualização o professor usa, em primeiro lugar, jornais e revistas; em segundo lugar, cursos de atualização; e em terceiro lugar, obras especializadas. Numa proporção de $50 \%$ dos professores das entrevistas estruturadas, percebe-se a indicação também de utilização de paradidáticos e/ou vários livros didáticos. Ao longo da carreira, os professores afirmam ter adquirido livros especializados, principalmente de História do Brasil, e alguns de temas específicos. Uma pequena parcela afirma também ter adquirido obras de temas mais contemporâneos. Contraditoriamente, a atualização através da produção historiográfica dos vários campos e canteiros da História não representa, pelas entrevistas, uma dificuldade para o professor. No entanto, a 
maioria não adquire novas produções, utilizando apenas o material disponível nas bibliotecas e, dentre os que se atualizam, o fazem nas temáticas e recortes cronológicos que mais necessitam em determinado momento ou que mais thes interessam. Mencionam como justificativa: "o difícil acesso é no sentido de dinheiro para comprar material atualizado" (Depoimento 20). "Os livros são caros, dificultando o acesso do professor, devido a sua remuneração, [por isso], costumo pesquisar em biblioteca pública e comprar alguns livros essenciais" (Depoimento 37). "Além de conseguir livros especializados procuro consultar bibliotecas e a Internet" (Depoimento 35).

É possível concluir pela verbalização dos professores, que não é suficiente para sua formação ter o mínimo de domínio profissional constituído de "remendos" pedagógicos e de pequenos impulsos individualizados para exercer bem o seu ofício. A formação deve pressupor também uma valorização dos aspectos contextuais e organizativos orientados para a mudança no sentido de resolver os problemas escolares e superar a perspectiva individualista de aperfeiçoamento dos professores.

\section{Ensino de História: representações e prática docente no Ensino Médio}

Um dos objetivos da nossa pesquisa é perceber como as reformas educacionais, as mudanças na legislação e no currículo chegam à sala de aula, na prática dos professores. Nesse período que estamos estudando, a disciplina escolar de História passou por várias mudanças: a primeira após a Lei 5692, em 1971; a partir de 1980 o ensino de História passa a ser repensado, discutido nacionalmente em seminários, congressos e em encontros regionais e nacionais, envolvendo especialistas dos três graus de ensino. Fruto desses debates e da participação de vários setores organizados tem início um processo de revisão curricular em todo o país.

No Estado do Paraná, para o Ensino Médio, foi elaborada uma nova proposta curricular, concluída em 1988, que não pretendia ser um "guia curricular" e sim o início de um processo pedagógico, um ponto de partida das ações educativas, devendo, portanto, ser objeto de análise e discussões constantes. (SEED/PR, REESTRUTURAÇÃO DO ENSINO DE $2^{\circ}$ GRAU, p. 2).

Essa proposta curricular foi produzida pela equipe pedagógica da SEED com representantes dos professores e consultoria de profissionais da UFPR. A 
proposta reflete uma preocupação do momento, ou seja, de contrapor a idéia de que ensinar história é repassar informações sobre todo o passado, dividido em compartimentos isolados e periodizados de forma rígida. Os autores da proposta defendiam que a construção e a consolidação da sociedade burguesa deveriam ser o cerne do ensino de História no segundo grau e desta forma se articulariam as demais instâncias e momentos:

0 capitalismo que historicamente institui uma ordem mundial, em todos os níveis, é o eixo central da análise. História do Paraná, do Brasil e da América podem e devem ser abordadas por um ângulo de análise que procure dar conta do conjunto, dos elementos comuns, das determinações e condicionamentos, dos inter-relacionamentos, tanto das dinâmicas específicas das regiões, das culturas e das sociedades. [...] Nossa proposta procura ao mesmo tempo: articular os diversos conteúdos em torno de um eixo comum de análise; evitar a hierarquização de base geográfica (História Geral/ Da América/ do Brasil/ do Paraná), valorizar a História regional sem cair na armadilha de pensá-la autônoma, independente de outras estruturas; proporcionar uma ligação com o presente, seus problemas e esperanças através da análise do processo histórico que constitui a nossa sociedade; levar em consideração os diversos níveis de temporalidade desse processo; abrir a disciplina de História no segundo grau para os avanços teóricos e metodológicos da ciência histórica; indicar caminhos concretos para o aperfeiçoamento e atualização dos professores da disciplina; incentivar um pensar sobre a História, analítico e crítico, no qual a própria produção do conhecimento histórico seja compreendida e discutida". (Reestruturação do $2^{\circ}$ grau no Paraná: Divulgação Técnica do Departamento de Ensino de $2^{\circ}$ Grau da SEED, 1988).

Durante a década em que a proposta sugerida ficou como uma opção para os professores, ela sofreu um processo de rejeição inicial por ser demasiada complexa e principalmente por não dar conta de toda a História. Na entrevista dirigida a alternativa mais assinalada foi o compromisso com a proposta curricular do Estado do Paraná de 1988, ou seja, 59\% dos professores afirmam que ainda trabalham com a proposta. Porém $28 \%$ manifestam restrições a ela, em respostas como: 
A proposta parte do pressuposto de que os alunos já têm um embasamento teórico para discutir e isso não é verdade. Então você pára e resgata os conhecimentos que são pré-requisitos ou não consegue se fazer entender. (Depoimento 25).

Ao trabalhar com a proposta percebi que ela abre um leque grande, podem aparecer dificuldades para adequar o currículo de uma escola a outra. (Depoimento 29).

Muitas vezes temos que inserir conteúdos do vestibular, visto que este é o objetivo de muitos alunos. (Depoimento 37).

Porém, nas entrevistas abertas realizadas, fica evidente que as escolas das quais os cinco professores entrevistados fazem parte praticamente descartaram a proposta, principalmente por que o currículo não incluía no Ensino Médio a História Antiga. Alguns usavam de artifícios para complementar esta periodização:

Nós tivemos que modificar essa parte aí, se não me engano, no ano retrasado pro passado a gente mudou. Não era dada a Pré História, então a gente dava por um livro da $7^{\mathrm{a}}, 8^{\mathrm{a}}$ série [...] dava uma revisada pra introduzir lá o Feudalismo. [...] Falava um pouco da cultura egípcia, grega, romana." (Professora Maria de Fátima, 2002).

Essa proposta só funciona se você trabalha desde $01^{\circ}$ grau. Porque há uma ruptura. Tem que ser dado Antiguidade no $2^{\circ}$ grau. Eu trabalho no $1^{\circ}$ ano com Idade Antiga e Medieval. No $2^{\circ}$ ano o fim da Idade Média, até hoje. A História do Brasil vai encaixando. Em 2000, nos 500 anos, eu trabalhei muito com Brasil. (Professora Marlene, 2002).

Até que nós chegamos a fazer uma renovação bastante grande, quando 0 planejamento iniciou-se a partir da Idade Média, na História do Capitalismo, na Baixa Idade Média e a evolução do Capitalismo no mundo ocidental. Depois disso houve novamente uma retomada do currículo antigo, quer dizer, é a manutenção do currículo do Ensino Médio, acrescentado da História Antiga, em função do vestibular. Porque queira ou não queira, nós temos o problema do vestibular no final do processo. Então para os alunos não sentirem tanta deficiência. (Professor Edson, 2001). 
Percebe-se também nas falas uma concepção de currículo associada a conteúdo, pois a crítica que os professores fazem ao currículo de 1988 ressalta bastante essa questão. Segundo MOREIRA,

a literatura especializada tem registrado, ao longo dos tempos, diferentes significados para a palavra currículo. Dominam, dentre eles, os que associam currículo a conteúdos e os que vêem currículo como experiências de aprendizagem. Outras concepções apontam para a idéia de currículo como plano, como objetivos educacionais, como texto e, mais recentemente, como quase sinônimo de avaliação. Minha opção é admitir a importância e a necessária articulação dos diferentes elementos enfatizados em cada uma das concepções apresentadas e, ao mesmo tempo, considerar o conhecimento como a matériaprima do currículo, [...] como o conjunto de experiências de conhecimento que a escola oferece aos estudantes. (2001, p.41-42).

Hoje há no Brasil um clima de renovação curricular, sugerido pelos PCNs, que parece não atingir a prática dos professores de História do Ensino Médio, em Curitiba. A grande maioria informa ainda seguir os conteúdos do currículo anterior, de 1988, embora muitas vezes com algumas adaptações. Sobre os PCNs, percebe-se um silêncio nas entrevistas dos professores, com algumas colocações esparsas, demonstrando um certo desconhecimento dessa nova proposta:

Aqui na escola funciona assim: segue-se em linhas gerais o regimento da escola e os PCNs. Mas assim em linhas gerais, porque dentro da sala de aula e entre os professores definem-se algumas atitudes que nem sempre estão de acordo com 0 regimento (Professor Ariosvaldo, 2002).

No instrumento dirigido, quando perguntado sobre questões que remetem ao saber disciplinar, percebe-se, pelas respostas, que o professor tem noção de quais ações didáticas ele deve adotar, tem noção da importância dos conceitos, das noções que são próprias para a produção de um saber escolar em História. 0 posicionamento dos professores sugere um discurso pronto, esperado pelas discussões pedagógicas atuais, ou seja, o professor tem clareza daquilo que é 
esperado dele enquanto um profissional da área de História e tem noção da diferença entre o trabalho a ser feito no Ensino Médio e Fundamental. Quando inquirido, ele responde que, no Ensino Médio, o aluno pode ser mais exigido quanto ao domínio de conteúdo, com relação a uma maior autonomia, e, principalmente, revela que esse é um momento da escolarização em que é possível trabalhar com pesquisa. Vejamos uma das falas que remetem a essa questão do trabalho diferenciado com o Ensino Médio:

Pois o conhecimento não está só nos livros. Os livros são uma forma, e nós não podemos nos fixar em uma forma. É muito gostoso, por exemplo, andar com os alunos nas ruas, nas trilhas da Serra do Mar. [...] Os projetos foram muitos. Um dos mais interessantes foi levar os alunos até Paranaguá, a partir do Museu em Paranaguá a gente aprofundou os temas de meio ambiente, com o mangue, levamos a molecada até... eles entraram no barro. Na maior imundície. Tivemos que vir sujos para Curitiba. [...]

Outro projeto interessante foi esse de andar pela rua, da gincana, de identificar a paisagem, identificar os estilos, identificar os personagens de época, os proprietários das casas, os arquitetos, os engenheiros, não tinha aquilo naquela época, os temas que mais predominam nas fachadas e uma outra coisa: os bilhetes, as cartinhas, as receitas de comida, as receitas de remédios, as poesias de amor, encontradas no 19 de dezembro, no jornal. [...] Na verdade eu estava trabalhando com os meus alunos, não como se fossem alunos de $2^{\circ}$ grau, mas como se fossem alunos de faculdade. É pesquisa mesmo. (Professor Edson, 2001).

Poderíamos afirmar que alguns professores conseguem perceber 0 currículo como um currículo integrado:

Optar por um currículo integrado implica modificar o contexto do trabalho escolar; obriga a transformar a organização dos recursos da escola e das salas de aula, torná-los visíveis nas estantes e ao alcance das mãos dos/as estudantes; criar as condições para melhorar a conexão da escola com o mundo exterior; elaborar estratégias para que outras pessoas e profissionais da comunidade tenham acesso à comunicação com os alunos; planejar maior número de visitas às instituições locais, para tomar contato com pessoas fora da escola; trabalhar de maneira mais coordenada e cooperativamente, etc. (SANTOMÉ, 1996, p. 67). 
Acreditamos que o fato do professor estar consciente do significado da recomposição didática ajuda-0 a escolher, mas também a avaliar e a contribuir para reduzir a distância entre saberes acadêmicos e o saber ensinado. Além disso, também ajuda a conduzir um maior número de alunos à compreensão do objeto a ser ensinado. Todavia, a prática não se reduz às ações do professores. Vários contextos interferem no seu trabalho, ele tem que superar uma série de limitações da profissão, ou seja, o baixo estatuto da profisss̃̃o docente, falta de infra-estrutura na escola, turmas com número elevado de alunos, poucas aulas por série, dificuldade de acesso a cursos na formação continuada, e por vezes, se defrontar com a imagem idealizada da profissão.

0 professor tem que lidar com uma série de práticas educativas de caráter interno ou externo à escola que podem ser classificadas como: práticas institucionais, organizativas, didáticas e concorrentes. Dessa forma, entendemos que o professor é responsável pela modelação da sua prática, mas esta é a intersecção de diferentes contextos: "0 docente não define a prática, mas sim 0 papel que aí ocupa; é através da sua auração que se difundem e concretizam as múltiplas determinações provenientes dos contextos em que participa". (SACRISTÁN, 1995, p. 74).

IIm dos fatores jábastante divulgados pelas pesquisas (CAVACO, 1995, ESTEVV, 1995) que afeta o trabalho docente, e, consequientemente, a produção do saber escolar, é a mobilidade dos professores de escola em escola, pois impossibilita o trabalho em equipe e prejudica a continuidade das atividades com a disciplina. Observamos essa questão na fala de um dos professores sobre sua experiência:

Tem um segundo ano que eu fui o quarto professor, foram mudando de professor a cada dois meses. Eles foram muito prejudicados. Teve uma professora que era padrão, que era assim ortodoxa, depois chegou um professor que era agitador político, mudou completamente a linha de pensamento dos alunos. Veio uma professora substituta que não fez mais que mandar fazer exercícios, depois eu peguei a turma. Os alunos não sabiam o que pensar. Eu tive que voltar o conteúdo, limpar as idéias de que os professores falaram, não que tivesse errado, mas estava tudo inisurado. Então eu tive que começar tudo de novo. Então esses alunos foram prejudicados. Esse problema da mobilidade dos professores na escola hoje é muito grande e isso prejudica bastante tudo o que estamos falando hoje: planejamento, conceitos, tudo, tudo. (Professor Ariosvaldo, 2002). 
Essa singularidade da análise do professor nos mostra 0 grau de improvisação que produz o sistema educacional e de que forma isso afeta os alunos e 0 trabalho com as disciplinas.

0 professor percebe e analisa as dificuldades que enfrenta na sua prática, adverte que não há orientação metodológica no cotidiano da escola e reclama da ausência de uma equipe pedagógica que direcione o trabalho para um planejamento coletivo, seja pelas próprias condições de trabalho que inviabilizam uma ação de estudos compartilhados. Uma demonstração dessa dificuldade pode ser observada na entrevista aberta com um professor que atua na maior escola de ensino médio do Paraná:

Quando eu cheguei aqui no Ensino Médio, eu vim para o Colégio Estadual em 91, encontramos o currículo antigo, ainda da 5692, uma resistência gigantesca por parte dos professores na mudança, em relação a mudança que deveria ser feita. Um exemplo disso era o planejamento: como que se fazia o planejamento? Muito simples. Vamos fazer o planejamento do ano. Pega-se o planejamento do ano anterior e copia-se. Está pronto o planejamento. Não foi feito planejamento nenhum, não foi feita pesquisa nenhuma, não houve uma discussão aprofundada. (Professor Edson, 2001).

A fala do professor sobre o planejamento é referendada pelos outros professores entrevistados e percebe-se que houve uma mudança gradativa, quase uma descrença nesse tipo de estratégia nas escolas:

A gente tenta fazer um planejamento coletivo, mas é muito difícil porque os professores são oriundos de várias camadas sociais, cidades diferentes, então é muito difícil fazer um planejamento. Existe um planejamento de História vinculado ao regimento, ao Estado. A cada ano nós o refazemos, adaptamos. Mas esse currículo não é seguido. Ele tem efeito burocrático. Até quem fez esse currículo fui eu (risadas), há 12 anos. Ele fica ali pra gente mostrar. Mas como a gente tem o livro didático adotado, então a gente segue o livro. Apesar de nós termos um currículo, aliás um regimento da escola, os currículos das várias disciplinas, eu afirmo pra você que a maioria dos professores não conhece isso. Não por não ter acesso, mas não procura, não tem interesse. [...] Essa falta de informação, também há o desinteresse da supervisão, que deveria promover reuniões sobre 
isso. Os horários não combinam, são turnos diferentes. Talvez se fizesse reuniões no sábado. Mas se você falar pros professores pra fazer reuniões no sábado ele te mata (risos). Então, é a falta de informação e desinteresse de ambas as partes: supervisão e professor. (Professor Ariosvaldo, 2002).

Uma das professoras entrevistadas, Maria Irmínia, que atuou antes da reforma de $1^{\circ}$ e $2^{\circ}$ graus, conhecida como lei 5692/71, afirma que conheceu uma escola muito diferente daquela que surgiu após essa mudança na legislação educacional: havia uma carga horária menor para cumprir - um total de10 horas/aula em um padrão -, com a atuação dos coordenadores de área, com planejamentos coletivos, professores sendo recebidos pela escola, orientados na fase inicial pelo coordenador de área, uma escola que podia comprar livros que os professores escolhiam e, principalmente, uma escola em que professores de História e Geografia conversavam, discutiam de que forma uma disciplina poderia estar contribuindo com a outra, o livro didático não era o centro do saber escolar. Era, como deveria ser, um coadjuvante. "Aquilo (a lei 5692/71) caiu como uma bomba atômica em cima dos professores". Foi um momento, segundo ela, em que se perdeu a liberdade de trabalhar os conteúdos, pois colocou os professores em contato com os chamados objetivos pedagógicos, aumentou a carga horária do professor em sala de aula, diminuiu a carga horária das disciplinas e começou o processo de massificação do ensino e a conseqüente inviabilização de um trabalho diferenciado.

Essa constatação da professora sugere a passagem de um sistema de ensino de elite para um sistema de ensino de massas, sem que o aumento do número de professores acompanhe o aumento do número de alunos, com 0 aparecimento de novos problemas, que nem sempre os professores, acostumados com alunos mais homogeneizados pela seleção que a escola fazia, sabiam resolver. Resulta daí esse sentimento de desencanto que afeta outros tantos professores na atualidade, quando comparam outros tempos com a realidade enfrentada na sala de aula em que trabalham:

Hoje não há respeito pelo professor, o aluno no corredor esbarra em você. Tem a questão salarial. Por ouiro lado o professor não deve levar esses problemas para. a sala de aula. Ali ele tem que dar aula. Tem professor que não dá aula. Só 
reclama, reclama. 0 próprio aluno vem reclamar que o professor não dá aula. Eu acho que a gente não deve misturar as coisas. Mas a situação é muito diferente. Quando eu comecei com um ano de trabalho você comprava um fusca, que era 0 carro da época. Hoje está difícil. (Professora Marlene, 2002).

Esse sentimento de insegurança reflete o ceticismo e a descrença em relação a qualquer política de reforma educativa. Em 30 anos, três propostas de mudanças foram, ou impostas, ou sugeridas, mas o que mudou efetivamente em sala de aula? Que outra relação de saber se estabeleceu com essas mudanças? A nossa hipótese é a de que as propostas de mudanças são tão rapidamente discutidas e implantadas que, na prática, o professor faz apenas uma pequena adaptação frente às exigências oficiais, cumprindo na superfície as orientações, sem que necessariamente haja uma mudança de fundo. É óbvio que não dá para generalizar, pois entra em jogo a formação do professor - até que ponto ele compreende os objetivos da reforma -, e as resistências pela descrença na eficácia da mudança proposta. Quando se sugere uma mudança, há os que mais facilmente aderem e os que resistem a elas. A gestão pessoal do equilíbrio entre a rigidez e a plasticidade define modos distintos de encarar a profissão docente. Quando indagado sobre essa questão, o professor Edson faz uma análise que reforça a nossa proposição:

Na verdade a mudança ocorre devido a uma somatória de influências: vontade do professor de mudar, novas informações, mesmo assim a respeito da própria disciplina que os professores tem acesso. Alguns documentos oficiais que esclarecem o rumo a ser seguido. Então a gente percebe, por ex., com muita clareza, as mudanças propostas cada vez que ocorre transformação na administração pública. Mudou o governo de Estado muda todo o secretariado e muda toda proposta de atividade pedagógica. Consequentemente a atividade do professor passa a ser afetada. Mas essa transferência de atividade docente não é tão intensa como deveria ser. Chega assim um eco da mudança. Nós temos, ao longo desses anos, observado muita resistência à transformação. (Professor Edson, 2001).

Essa avaliação reforça que há uma tensão, um conflito entre o que é proposto como norma, como um saber a ser ensinado e o professor. Há hoje 
uma intensificação do trabalho cotidiano nas escolas, resultado da qual os professores são chamados a cumprir outras tarefas, a ampliar as suas funções. Por outro lado, cresce o controle institucional e ele é cada vez mais cobrado pela comunidade. Ao mesmo tempo ele acompanha as renovaçoes constantes dos programas e currículos, de novas formas de gestão da escola. Tudo isso acaba provocando momentos de tensão e uma necessidade de constante adaptação.

Olhe, eu observei que está havendo um prejuízo muito grande. Antigamente os assuntos do planejamento eram mais sintonizados, mais direcionados e hoje eles estão gerais demais. Ao generalizar, o aluno está tendo uma visão geral, está certo que ele tem que ter uma visão mais ampla, mas é uma visão meio perdida. Está tão ampla que ele não acha o caminho. Antigamente você mosirava só o caminho. Hoje é o contrário. Ele sabe o todo mas não tem o caminho. Então pra mostrar o caminho fica difícil.

os planejamentos e as aulas estão relegados a segundo plano. Hoje valoriza-se muito o planejamento geral da escola, a norma geral. Os planejamentos de aula estão em segundo plano. Não se reúnem mais os professores para fazer planejamento de aula. Eu gostava desses planejamentos mais direcionados, porque era direcionado, o assunto era esmiuçado[..]. Hoje com todas essas mudanças. Você trabalha com paradigma, mas ninguém sabe o que é um paradigma. Nossa escola, por exemplo, eu tenho observado, não há uma preocupação com o planejamento de aula. Nós somos em seis professores de história, professores padrão (Professor Ariosvaldo, 2002).

0 caminho projetado pelos depoimentos - estruturados e os abertos como um importante meio de romper o isolamento profissional, estaria na valorização do trabalho em equipe, pois para alguns professores essa medida contribuiria para a 'atualização', 'para trocar experiências'. Uma diferença significativa entre os dois tipos de entrevistas foi a de que, para uma ampla maioria dos professores que responderam às questões estruturadas, a proposta curricular é o ponto de partida para o planejamento coletivo da escola. Enquanto que professores da entrevista aberta quando se referem à escola atestam que esse planejamento coletivo não é norma, muitos não conhecem as propostas curriculares e não a seguem. No entanto, o livro didático adotado 
coletivamente como norteador da organização curricular da disciplina atinge um terço dos professores inquiridos, bem como três dos cinco professores que participaram da entrevista aberta:

Eu sei que a maioria dos historiadores afirma, "ah, o professor não deve trabalhar com o livro". Eu já sou mais da linha tradicional... acho que tem que trabalhar com o livro. É um instrumento que eles (os alunos) têm... (Professora Maria de Fátima, 2002).

Se nós temos o livro didático eu não posso chegar em aula trazendo um programa novo. Eu tenho que acompanhar a sequiência da matéria, aquilo que estamos trabalhando, senão cria confusão no aluno. Eu posso trabalhar com outro tema, faço xerox e trago, mas relacionando com aquilo que estamos trabalhando. Mas 0 aluno não está habituado a trabalhar com temas. (Professor Ariosvaldo, 2002).

Isso significa que grande parte dos professores são consumidores de práticas esboçadas fora do teatro imediato da ação escolar e que talvez as editoras de manuais didáticos e outros produtores de materiais escolares exercem mais influência nas escolas do que os próprios professores ou a própria legislação. Essa situação poderia ser superada, em parte, se a responsabilidade na formação inicial do professor não se restringisse às disciplinas pedagógicas. Elas têm um papel central na contribuição dessa formação, mas é fundamental para o professor 0 conhecimento seguro e profundo da disciplina de História e a articulação desse saber com as exigências do ensino de primeiro e segundo graus.

A formação do professor de História sofre, de certa forma, influência dos caminhos e territórios marcados pela sua disciplina. A história experimenta um crescimento sistemático, seja pelo aumento contínuo de documentação (alimentada por novas fontes de informação e pela construção de novos objetos) seja pela influência de outros campos de investigação dentro das humanidades, e fora delas, que ampliam o campo da interpretação e os domínios do historiador. Essa ampliação dos campos da história pode enriquecer, mas pode, a mesmo tempo, dificultar o processo de formação do professor de história. Pode dificultar na medida em que não se leva em consideração que um dos objetivos de um curso de história é a formação do professor. Segundo Jacques Plante, "para 
formar historiadores, não basta ensinar-lhes história. 0 currículo de formação deve permitir-lhes integrar todos os tipos de saberes e de saber-fazer numa prática profissional" (apud PERRENOUD, 1993, p. 157).

\section{Considerações Finais}

Podemos ressaltar que analisar o que é específico da profissão de professor de História é não desconsiderar todas as implicações do que é específico da ação docente. É necessário mostrar as diferenças e a diversidade de fatores e modos de acesso à experiência do passado, diferenciando, se possível, uma visão idealizada da realidade concreta do ensino. Trabalhar com a memória é recuperar, em certo sentido, as representações que os grupos modelam deles próprios ou dos outros, é entender o professor construindo a sua experiência com mais ou menos liberdade, com mais ou menos condições, efetuando práticas demarcadas, modeladas na descontinuidade das trajetórias históricas (CHARTIER, 1990, p.25-27).

A partir de nossas análises sobre o impacto da formação nas representações do professores, inferimos que no início da carreira predominou na escola a desinformação sobre as normatizações oficiais, quer dizer, o professor não é introduzido na escola, ele leva um choque de realidade, pois desconhece 0 funcionamento da escola, sente dificuldades no processo de avaliação dos seus alunos e na maioria das vezes se vê obrigado a tomar decisões e não tem com. quem compartilhar suas dúvidas e angústias. Outro aspecto da formação que pesou na atividade prática em sala de aula, ressaltado pelos professores, foi a dificuldade em traduzir para os fins de ensino a produção acadêmica da disciplina de História.

Distinguimos entre os professores entrevistados traços de identificação, como por exemplo o fato de terem lecionado um longo período com o Ensino Fundamental e somente após um período de experiência em outros graus de ensino assumirem um trabalho no Ensino Médio. Porém existem outras características que nos permitem diferenciá-los: o professor Edson e a professora Maria Irmínia têm em comum um histórico familiar e um processo de formação bastante aproximado. Formados em História em uma Universidade Pública, com uma luta de muitos anos em participação coletiva na escola em defesa do 
ensino de História, não optaram ou não precisaram trabalhar com outra disciplina escolar, enfim, tendo uma relação distinta com a disciplina de História. Os outros três identificam-se por terem feito outro curso superior - Filosofia ou Estudos Sociais - e por complementar a formação em História. Esses professores trabalharam ao longo da carreira com outras disciplinas, exerceram outras atividades fora do magistério e essas opções parecem interferir na sua prática como professores de História, ou seja, não demonstram a mesma relação profunda com a disciplina, uma identificação como professores de História por opção, como ocorre com os outros dois professores.

Finalmente pensamos que discutir os fins e as práticas a partir da fala do professor leva também à discussão sobre a profissionalidade, sobre a identidade do professor, pois a memória é um elemento constituinte do sentimento de identidade, tanto individual como coletiva (POLLACK, 1992, 201) e pode levar o professor entrevistado a se interrogar sobre a sua própria relação com o saber, sobre seus métodos, sobre a sua relação com a disciplina de História e sobre as representações que podem guiar suas escolhas ou tomadas de decisões.

\section{Bibliografia}

ALTET, Marguerite. As competências do professor profissional: entre conhecimentos, esquemas de ação e adaptação, saber analisar. In: PAQUAY, Leopold, PERRENOUD, Philippe, ALTET, Marguerite, CHARLIER, Evelyne. Formando professores profissionais: quais estratégias? Quais competências? Porto Alegre: Artmed Editora, 2001. p. 23-36.

BAILLAUQUES, Simone. Trabalho das representações na formação dos professores. In: PAQUAY, Leopold, PERRENOUD, Philippe, ALTET, Marguerite, CHARLIER, Evelyne. Formando professores profissionais: quais estratégias? Quais competências? Porto Alegre: Artmed Editora, 2001. p. 37-54.

CATANI, Denice Bárbara. Estudos de História da Profissão Docente. In: LOPES, Eliane; FARIA F ${ }^{\circ}$, Luciano; VEIGA, Cynthia. 500 Anos de Educação no Brasil. Belo Horizonte: Autêntica, 2000. p. 585-99.

CAVACO, Maria H. Ofício do Professor: o tempo e as mudanças. In: NÓVOA, Antonio (Org.) Profissão Professor. Portugal: Porto Editora, 1995. p.155-91.

CERTEAU, Michel. A escrita da história. Rio de Janeiro: Forense Universitária, 1982. 
CHARTIER, Roger. A História Cultural: entre práticas e representaçôes. Rio de Janeiro: Difel / Bertrand Brasil, 1990.

CHARTIER, Roger. A história do tempo presente, IN: FERREIRA, Marieta de M.; Amado, Janaína. (org.) Usos e abusos da História Oral. Rio de Janeiro, Fundação Getúlio Vargas, 1996.

ESTEVES, José M. Mudanças Sociais e Função Docente, In: NóVOA, Antonio (Org.) Profissão Professor. Portugal: Porto Editora, 1995. p. 93-120

GOODSON, Ivor F. Dar voz ao professor: as histórias de vida dos professores e o seu desenvolvimento profissional. In: NÓVOA, Antonio. (Org.) Vidas de professores. 2. ed. Lisboa: Porto, 1995. p. 63-78.

HALBAWCHS, Maurice. A memória coletiva. São Paulo: Vértice, 1990.

JULIA, Dominique. A cultura escolar como objeto histórico. In: Revista brasileira de História da Educação, Campinas: Editora Autores Associados, n.1, jan/jul. 2001. p.9-43.

KENSKI, Vani Moreira. Memória e prática docente. In: BRANDÃo, Carlos Rodrigues. (Org.) As faces da memória. Campinas: Centro de Memória - UNICAMP, (19-). P. 101-114.

LE PELLLEC, J.; MARCOS ALVAREZ, V. Enseigner l'histoire: un métier qui s'apprend. Paris, Hachette Éducation, 1991.

MOREIRA, Antonio Flavio Barbosa. As reformas curriculares como instrumento de controle da escola, do profesorado e do aluno. Revista Educar:,....19-

PERRENOUD, Philippe. Práticas pedagógicas, profissão docente e formação: perspectivas sociológicas. Lisboa: Dom Quixote, 1993.

POLLACK, Michael. Memória e identidade social. In: Estudos Históricos, Rio de Janeiro, vol.n. 5 , n.10, p. 200-215.

SACRISTAN, J.Gimeno. Consciência e Açção sobre a Prática como Libertação Profissional dos Professores. In: NóVOA, Antonio. (Org.) Profissão Professor. Portugal: Porto Editora, 1995. p. $63-88$.

SANTOMÉ, Jurjo Torres. A instituição escolar e a compreensão da realidade: o currículo integrado. In: SILVA, Luiz H; AZEVEDO, José C. (Org.) Novos mapas culturais, novas perspectivas educacionais. Porto Alegre: Sulina, 1996.

SECRETARIA DE ESTADO DA EDUCAÇÃO. Reestruturação do ensino de Segundo Grau: Projeto de Conteúdos Essenciais do Ensino de Segundo Grau - História. Curitiba, novembro de 1988. 
SECRETARIA DE ESTADO DA EDUCAÇÃO. Relatórios Ensino de Se.z.....in (irau - 1980 , 1986, 1988.

SPINK, Mary Jane. Desvendando as teorias implícitas: uma metodriculi: je análise das representaçoes sociais. IN: JOVECHELOVITCH. Sandra \& GLARES(HII, P (org) Textos em representações sociais. Petropólis: Vozes, 1994.

\section{PROFESSORES ENTREVISTADOS}

CRUZ, Ariosvaldo Trancoso. Entrevista realizada em Curitiba, 11 de dezembro de 2002. FERNANDES, Maria de Fátima. Entrevista realizada em Curitiba, 27 de abril de 2002. HOFFMANN, Marlene. Entrevista realizada em Curitiba. 30 de janeiro de 2002.

VIEIRA, Maria Irmínia C. Entrevista realizada em Curitiba, 21 de maio de 2002. OLIVEIRA, Edson L. Entrevista realizada em Curitiba, 10 de outubro de 2001.

\section{Educational Profession: Formation and Practice of History Teachers in the Medium Teaching}

\section{ABSTRACT}

The present article has for objective to present and to discuss the results of the research "The school discipline of History and the practice of the Medium Teaching teachers in State of Paraná: an analysis of the last thirty years", which has been accomplished by driven questionnaires and interviews with some History teachers that act or acted in the public net of the State, with the intention of rising aspects of their formation, of the teacher pedagogic doing, of the knowledge, analysis and application of the curriculum and their relationship with the History discipline. In this article we presented some subjects regarding the impact of the formation in the practice of those teachers, and to the representations and educational practice in the medium teaching.

Key-words: History teaching, formation and practice of teachers. 